\title{
MENENTUKAN STRATEGI PERMASARAN PADA PRODUK BRIKET DENGAN METODE GAME THEORY UNTUK MENINGKATKAN PENJUALAN DI UKM KAISAR BRIKET
}

\author{
Satria Ramadhani, Boy Isma Putra \\ Program Studi Teknik Industri \\ Universitas Muhammadiyah Sidoarjo \\ satriaramadhani4@yahoo.com
}

\begin{abstract}
UKM Kaisar Briket is one of the business sectors that briket produce. The problem is not enough briket product known to the public and the market competition, briket product compete with LPG and kerosene so that the competition is encouraging to be albe to search for the right marketing to strategy to compete in the market.the methode game theory can deetermine a marketing strategy through the marketing mix 4P (product, price, place, promotion). Marketing mix divided into severval attribute to know some of the marketing strategy that will be product advantage to attract users briket. Responden data required to obtain the value of matriks calculation game theory methode previously in reliability test and validitas test toknow what valid whether or not the responden data the result of the study showed the briket product have superior strategy and alternative strategies when competitions products.
\end{abstract}

Keyword : marketing, marketing mix, game theory

\begin{abstract}
ABSTRAK
UKM Kaisar Briket adalah salah satu bidang usaha yang memproduksi briket. Permasalahannya adalah produk briket belum cukup dikenal masyarakat dan dalam persaingan pasar produk briket bersaing dengan produk elpiji dan minyak tanah sehingga persaingan ini mendorong untuk bisa mencari strategi pemasaran yang tepat untuk mampu bersaing di pasar. Dengan metode teori permainan dapat menentukan strategi pemasaran melalui bauran pemasaran 4P (produk, harga, tempat, promosi). Bauran pemasaran dibagi menjadi beberapa atribut untuk mengetahui beberapa strategi pemasaran yang akan menjadi keunggulan produk untuk menarik minat penguna briket. Diperlukan data responden untuk mendapat nilai dari perhitungan matriks pada metode teori permainan yang sebelumnya di uji reliabilitas dan validitas untuk mengetahui valid atau sahih pada data responden. Hasil penelitian menunjukan produk briket mempunyai strategi unggul dan strategi alternatif ketika dibandingkan dengan produk pesaing.
\end{abstract}

Kata kunci : Pemasaran, Bauran pemasaran, Teori permainan

\section{PENDAHULUAN}

Di zaman modern seperti sekarang ini mulai terasa krisis bahan bakar minyak bumi dikarenakan pasar yang kurang memberi inovasi berupa alternatif bahan bakar. Hal ini menuntut kita memiliki pengetahuan dan kemampuan untuk menentukan cara atau pandangan dalam memilih bahan bakar yang lebih tepat, efektif, dan hemat dengan membandingan produk lain. Adanya persaingan menuntut pengusaha dan perusahaan memikirkan sebuah strategi yang efektif terhadap produknya.

Briket adalah salah satu produk yang terbuat dari limbah (Program recycling) yang tepat untuk digunakan menjadi alternatif bahan bakar hanya saja briket bukan merupakan bahan bakar yang belum cukup dikenal masyarakat. Dari sini muncul ide penelitian terhadap produk bahan bakar untuk menjabarkan keunggulan dan kelemahan produk dengan 
menganalisa melalui pembauran pemasaran 4P (product, price, place, promotion) menjadi salah satu cara untuk memudahkan analisa dalam menentukan strategi terhadap penelitian dengan harapan meningkatkan penjualan dengan lebih meningkatkan variabel yang lebih unggul antara produk, harga, lokasi dan promosi pada bahan bakar briket,elpiji dan minyak tanah yang analisanya dibantu dengan mengunakan game theory (teori permainan).

\section{LANDASAN TEORI}

\section{A. Pemasaran}

Pada suatu usaha pasti terdapat sebuah persaingan antara usaha lain bahkan dengan perusahaan yang lebih besar yang dimana suatu usaha atau perusahaan dituntut untuk meningkat penjualan sesuai perkembangan jaman, menguasai pasar, sampai mempertahankan keunggulan pasar. Alasan paling mendasar dalam pemasaran ialah mempengaruhi hampir semua aspek kehidupan, banyaknya peluang yang menguntungkan dan mempunyai peranan menumbuhkan nilai ekonomi [6].

\section{Pengertian Pemasaran}

Pemasaran adalah kegiatan yang dilakukan oleh individu atau kelompok untuk menciptakan nilai ekonomi dari suatu produk. Nilai ekonomi yang dimaksud adalah ketika dalam pasar terjadi sebuah kontak jual beli antara produsen dan konsemen, dimana ketika konsumen meminta (permintaan) yang bervariasi sesuai segmentasi pasar, persaingan pasar mulai melakukan cara dan strategi berdasarkan organisasi masing-masing yang bertujuan mengikat konsumen untuk mendapatkan kesepakatan[5].

\section{Tujuan Pemasaran}

Tujuan pemasaran adalah konsumen potensial mengetahui secara detail terhadap produk, perusahaan menjelaskan secara detail hal yang berhubungan dengan pemasaran kepada konsumen dari pengenalan kualitas produk, harga produk, promosi produk dan pengiriman produk secara cepat, hingga konsumen paham secara detail pada produk [7].

\section{Konsep Pemasaran}

Konsep pemasaran memberikan kepuasan terhadap keinginan dan kebutuhan pembeli/konsumen. Seluruh kegiatan dalam perusahaan yang menganut konsep pemasaran harus diarahkan untuk memenuhi tujuan tersebut. Transaksi dan pertukaran merupakan inti dari konsep pemasaran yang dimana terdapat 2 pihak yang pada akhirnya mendapatkan kesepakatan. Orientasi konsep ini dibatasi oleh tujuan laba dan pertumbuhan, akan tetapi konsep itu perlu dilaksanakan di karena kan dapat memberi daya tarik pada kemudahan pembelian, seperti : Mudah penggunaan, mudah pembeliaannya dan mudah pemeliharaannya [6].

\section{Peran Pemasaran}

Peranan pemasaran terhadap konsumen ialah [6] :

1. Kebutuhan, segala kebutuhan dasar manusia baik intuk minum, makan, pakaian, pendidikan dan lainnya

2. Keinginan, merupakan kondisi lebih khusus dari kebutuhan, misalnya minuman ringan, makanan bergizi, pendidikan tinggi, atau lainnya

3. Permintaan, akumulasi kebutuhan/ keinginan yang potensial untuk digarap, misalnya, makanan, perumahan, pendidikan dan lainnya.

\section{B. Strategi Pemasaran}

\section{Pengertian Strategi Pemasaran}

Strategi pemasaran adalah strategi untuk melayani pasar atau segmen pasar yang dijadikan target oleh pengusaha, sehingga tinggi rendahnya penjualan ditentukan baik buruknya strategi pasar oleh pengusaha untuk mencapai tujuan organisasinya [11] 


\section{Tujuan Strategi Pemasaran}

Dalam suatu strategi pemasaran terdapat tujuan yang dicapai yaitu keinginan pelangan dan kepuasaan pelanggan maka terdapat acuhan terutama pada dimensi kualitas dalam menentukan strategi pemasaran yaitu [4]:

1. Reliabilitas, kemampuan memberi layanan yang dijanjikan dengan segera, akurat, dan memuaskan.

2. Responsivitas, keinginan dan kesediaan para anggota organisasi perusahaan untuk membantu dan memberi layanan dengan tanggap.

3. Jaminan, mencangkup pengetahuan, kompetisi, kesopanan, dan sifat yang dapat dipercaya yang dimiliki anggota organisasi perusahaan sehingga terhindar dari bahaya fisik, resiko atau keragu-raguan.

4. Empati, kemudahan dalam menjalin hubungan, komunikasi yang efektif, perhatian personal dan pemahaman terhadap kebutuhan pelanggan.

5. Bukti fisik, fasilitas fisik, perlengkapan, anggota organisasi, dan komunikasi.

Inti dari tujuan strategi pemasaran adalah kepuasan pelanggan. Kepuasaan pelanggan merupakan konsep sentral dalam wacana bisnis dan organisasi. Konsekuensi kepuasaan/ketidakpuasaan pelanggan menjadi hal yang kursial bagi kalangan bisnis, keadaan pasar, pengatur pasar dan konsumen [4]

\section{Konsep Strategi Pemasaran}

Perusahaan dapat memilih salah satu atau beberapa dari 4 strategi yang terjadi pada segmentasi pasar, yaitu [5] :

1. Undifferentiated marketing, strategi yang menganggap bahwa pasar yang ada, menjadikan produk atau jasa yang berkebutuhan sama, sehingga tidak ada segmen dalam tiap individu atau sosial.

2. Differentiated marketing, produsen membuat produk atau jasa yang memiliki ciri dan karakteristik yang berbeda-beda.

3. Concentrated marketing, strategi yang menfokuskan pada satu karakteristik yang dianggap mempunyai karekteristik yang berpotensi.

4. Multisegment marketing, perusahaan memilih 2 atau lebih pada segmen pasar dan menyusun bauran pemasaran yang lebih terpisah pada setiap segmen tersebut.

\section{Bauran Pemasaran (Marketing Mix)}

Ada beberapa faktor yang harus dipertimbangkan untuk mengambil keputusan secara efektif tentang peningkatan produk. Faktor-faktor tersebut merupakan bagian yang ada dalam sebuah Variabel untuk mengambil keputusan dalam menentukan hal yang ditonjolkan pada produk untuk menjadi senjata dalam persaingan pasar. Bauran pemasaran merupakan pemecahan permasalah pada tingkat penjualan yang dimana tiap variabelnya mempunyai pengaruh pada tingkat penjualan

\section{Pengertian Marketing Mix}

"Marketing mix is the set of marketing tools that the firm uses to pursue its marketing objectives in the market" kurang lebih memiliki arti, bauran pemasaran adalah kumpulan dari variabel-variabel pemasaran yang dapat dikendalikan yang digunakan oleh organisasi usaha untuk mencapai tujuan pemasaran dan sasaran pemasaran [8].

\section{Variabel- Variabel Marketing Mix}

Variabel marketing mix menjadi daya ukur kekuatan perusahaan atau organisasi dalam bersaing untuk mendapatkan konsumen dan keuntungan. Ada 4 variabel yang menjadi inti dalam persaingan pemasaran, Keempat variabel bauran tersebut dijelas sebagai berikut [11]:

\section{Produk}

Produk adalah segala sesuatu yang ditawarkan kepada masyarakat untuk dilihat, dipegang,dibeli dan dikonsumsi berdasarkan, variety, quality, design, feature, brand name, packing, sizes, servises, warrenties and returns 


\section{Harga}

Merupakan sejumlah uang yang dibayar oleh konsumen untuk membeli produk atau menganti hal milik produk. Harga meliputi last price, discout, allowance, payment period, credit trems, and retail price.

3. Tempat

Sebagian dari perusahaan untuk membuat produk yang tempatnya berdekatan dengan sasaran pasar yang lebih terjangkau dengan memikirkan tersedia bagi sasaran pasar. Tempat meliputi antara lain channels, coverage, assortment, location, inventory, and transport

\section{Promosi}

Kegiatan perusahaan dalam pengomunikasian atau penyampaian terhadap produk untuk memperkenalkan produk pada sasaran pasar. Promosi meliputi antara lain sales promotion, advertising, sales force, public relation, and direct marketing.

\section{Analisis Jalur Marketing Mix}

Menurut [13] menjelaskan bahwasanya adanya pola hubungan yang memperlihatkan eratnya hubungan variabel-variabel atau mengungkapkan pengaruh sebuah variabel atau seperangkat variabel terhadap variabel lainnya baik pengaruh langsung maupun tidak langsung. Pada pola hubungan variabel produk menjadi hal yang paling inti dalam penentuan strategi.

\section{Game Theory (Teori Permainan)}

\section{Pengertian Game Ttheory}

Game theory adalah suatu cara belajar yang digunakan dalam menganalisa interaksi antara sejumlah pemain maupun perorangan yang menunjukkan strategistrategi yang rasional. Kepentimgan-kepentingan yang bermain dalam permainan disebut pemain. Teori permainan pertama kali ditemukan oleh sekelompok ahli Matematika pada tahun 1944. Teori itu dikemukakan oleh John Von Neumann and Oskar Morgenstern yang berisi:

"Permainan terdiri atas sekumpulan peraturan yang membangun situasi bersaing dari dua sampai beberapa orang atau kelompok dengan memilih strategi yang dibangun untuk memaksimalkan kemenangan sendiri atau untuk meminimalkan kemenangan lawan. Peraturan-peraturan menentukan kemungkinan tindakan untuk setiap pemain. Sejumlah keterangan diterima setiap pemain sebagai kemajuan bermain dan sejumlah kemenangan atau kekalahan dalam berbagai situasi." [12]

\section{Unsur-Unsur Game Theory}

Ada pun unsur-unsur dasar teori permainan yang menguraikan dari cara teori permainan,sebagai berikut :

1. Angka-angka dalam matriks pay off menunjukan hasil-hasil dari strategi permainan yang berbeda-beda dan dinyatakan dalam suatu bentuk ukuran efektivitas, seperti uang, presentase, dan kegunaan.

2. Strategi permainan, rangkaian kegiatan yang menyeluruh dari seorang pemain atau strategi pemain, sebagai reaksi atas aksi yang mungkin dilakukan pesaing.

3. Aturan-aturan pemain, mengambarkan kerangka dengan mana para pemain memilih strategi mereka.

4. Nilai permainan,hasil yang diperkirakan tiap permainan atau pay off rata-rata dari sepanjang rangkaian permainan, dimana suatu permainan dikatakan "adil" apabila nilainya nol dan tidakada pemain yang memperoleh keuntungan atau kemenangan, dikatakan "tidak adil" jika nilainya bukan nol.

5. Strategi di katakan dominan bila setiap pay off dalam strategi adalah superior terhadap setiap pay off yang berhubungan dalam suatu strategi alternatif. Aturan dominan ini dapat digunakan untuk mengurangi ukuran matriks pay off dan upaya perhitungan. 
6. Strategi optimal, merupakan sebuah rangkaian kegiatan atau rencana yang menyeluruh, yang menyebabkan seorang pemain dalam posisi yang menguntungkan tanpa memperhatikan kegiatan-kegiatan para pesaingnya.

7. Tujuan dari model permainan adalah mengidentifikasikan strategi atau rencana optimal untuk setiap pemain.

Karena banyaknya asumsi-asumsi, maka nilai praktis teori permainan memiliki batas akan tetapi bagaimanapun inti manajerial dalam kondisi pesaing dalm bentuk konflik atau pun bekerjasama [12].

\section{Jenis Permainan}

Ada 2 macam strategi optimum yaitu strategi murni dan strategi campuran [9].

1. Pemain dengan strategi murni adalah suatu permainan dengan posisi pilihan terbaik bagi setiap pemain dicapai dengan memilih satu strategi tunggal. Dalam permainan strategi murni, pemain baris mengidentifikasikan strategi optimalnya melalui aplikasi kriteria maksimin sedangkan pemain kolom mengidentifikasikan strategi optimalnya melalui aplikasi kriteria minimaks.

2. Strategi campuran adalah strategi pemain mempunyai probabilitas yang menunjukan proposi waktu atau banyaknya bagian yang dipergunakan untuk melakukan strategi seperti metoda grafik, metoda analisis, metoda aljabar matriks dan metoda liniear programming.

\section{Matriks Game Theory}

Teori permainan membahas perilaku dua atau lebih pemain yang sedang terlibat dalam adu strategi dimana pilihan strategi salah satunya mempengaruhi strategi pemain yang lain. Dalam teori ini, dua pembuat keputusan yang saling berlawanan mengetahui informasi mengenai lawan dan mengetahui pula nilai permainannya. Layaknya sebuah persaingan, seorang pemain akan selalu memposisikan dirinya sebagai pihak yang harus memenangkan permainan, oleh karena itu dalam teori ini, pemain 1 diposisikan sebagai pemain yang memaksimumkan kemenangan dan pemain 2, diposisikan sebagai pemain yang meminimumkan kekalahan [10]

\section{METODOLOGI PENELITIAN}

\section{A. Variabel Penelitian}

Variabel penelitian berdasarkan pembauran pemasaran yang menjadi perbandingan antar produk bahan bakar dangan mengunakan variabel bebas, berikut variabelnya :
a. Produk $\left(\mathrm{X}_{1}\right)=$ Efisiensi dan Kualitas $\left(\mathrm{y}_{1}, \mathrm{x}_{1}, \mathrm{y}_{2}, \mathrm{x}_{2}, \mathrm{y}_{3}, \mathrm{x}_{3}, \mathrm{y}_{4}, \mathrm{x}_{4}, \mathrm{y}_{5}, \mathrm{x}_{5}, \mathrm{y}_{6}, \mathrm{x}_{6}\right)$
b. Tempat $\left(\mathrm{X}_{2}\right)=$ Ketersediaan berdasarkan wilayah $\left(\mathrm{y}_{7}, \mathrm{X}_{7}, \mathrm{y}_{8}, \mathrm{X}_{8}\right)$
c. Harga $\left(X_{3}\right)=$ Nilai ekonomis $\left(\mathrm{y}_{9}, \mathrm{X}_{9}, \mathrm{y}_{10}, \mathrm{X}_{10}\right)$
d. Promosi $\left(\mathrm{X}_{4}\right)=$ Daya tarik dan Promo $\left(\mathrm{y}_{11}, \mathrm{x}_{11}, \mathrm{y}_{12}, \mathrm{x}_{12}\right)$

B. Diagram Alir Penelitian

Diagram alir penelitian ini bertujuan mempermudah mekanisme jalannya pengerjaan penelitian ini secara sistematis. 


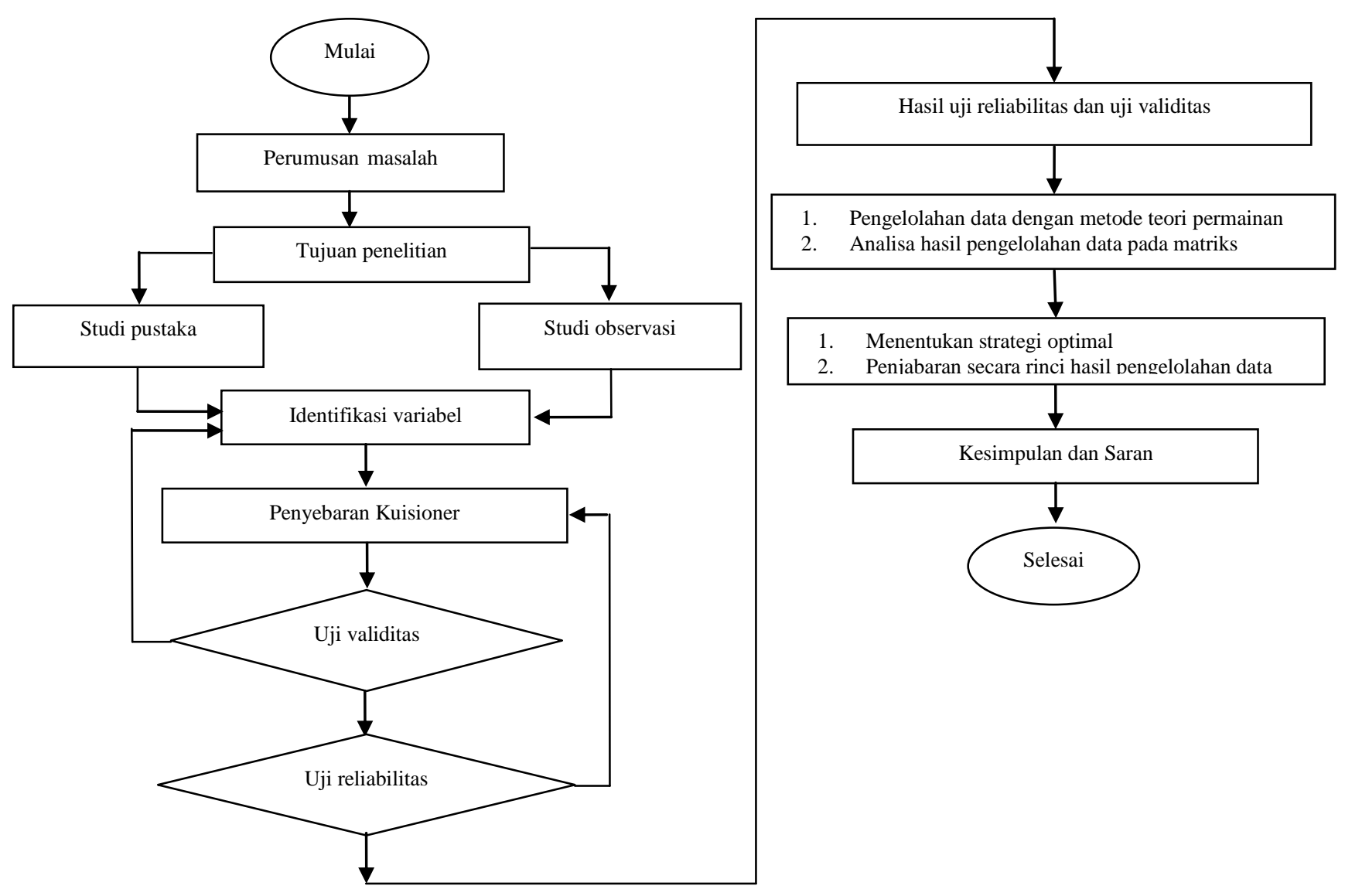

Gambar 1. Flowchart Penelitian

\section{HASIL DAN PEMBAHASAN}

\section{A. Hasil Uji Validitas dan Reliabilitas}

Uji validitas dan reliabilitas kuisioner tiap produk bahan bakar menggunakan bantuan Software SPSS 16.0. Hasil yang didapat dapat dilihat pada tabel dibawah ini:

Tabel 1. Output Uji Reliabilitas Hasil Kuisioner Bahan Bakar LPG

\begin{tabular}{|c|c|c|}
\hline R tabel & Alpha & Keterangan \\
\hline 0,468 & 0,867 & Reliabel \\
\hline
\end{tabular}

Pada tabel 1. diatas nilai Cronbach's Alpha adalah sebesar 0,867, nilai yang didapat lebih dari 0,468 , jadi hasil kuisioner untuk bahan bakar LPG dinyatakan reliabel. $($ Reliabel $=$ Cronbach's Alpha $>0,468)$

Tabel 2. Output Uji Validitas Hasil Kuisioner Bahan Bakar LPG

\begin{tabular}{|c|c|c|c|}
\hline Atribute & R hitung & R tabel & Keterangan \\
\hline 1 & 0,597 & 0,468 & Valid \\
\hline 2 & 0,643 & 0,468 & Valid \\
\hline 3 & 0,710 & 0,468 & Valid \\
\hline 4 & 0,646 & 0,468 & Valid \\
\hline 5 & 0,486 & 0,468 & Valid \\
\hline 6 & 0,509 & 0,468 & Valid \\
\hline 7 & 0,580 & 0,468 & Valid \\
\hline 8 & 0,568 & 0,468 & Valid \\
\hline
\end{tabular}




\begin{tabular}{|c|c|c|c|}
\hline 9 & 0,576 & 0,468 & Valid \\
\hline 10 & 0,550 & 0,468 & Valid \\
\hline 11 & 0,500 & 0,468 & Valid \\
\hline 12 & 0,670 & 0,468 & Valid \\
\hline
\end{tabular}

Pada tabel 2. diatas pada kolom Corrected Item-Total Correlation pada masing - masing atribut didapatkan nilai lebih dari $\mathrm{r}$ tabel 0,468 . Jadi hasil kuisioner pada produk bahan bakar LPG untuk masing - masing atribut dinyatakan valid.

Tabel 3. Output Uji Reliabilitas Hasil Kuisioner Bahan Bakar Minyak Tanah

\begin{tabular}{|c|c|c|}
\hline$R_{\text {tabel }}$ & Alpha & Keterangan \\
\hline 0,468 & 0,896 & Reliabel \\
\hline
\end{tabular}

Pada tabel 3. diatas nilai Cronbach's Alpha adalah sebesar 0,896, nilai yang didapat lebih dari 0,468 , jadi hasil kuisioner untuk bahan bakar minyak tanah dinyatakan reliabel. $($ Reliabel $=$ Cronbach's Alpha $>0,468)$

Tabel 4. Output Uji Validitas Hasil Kuisioner Bahan Bakar Minyak Tanah

\begin{tabular}{|c|c|c|c|}
\hline Atribute & R hitung & R tabel & Keterangan \\
\hline 1 & 0,796 & 0,468 & Valid \\
\hline 2 & 0,608 & 0,468 & Valid \\
\hline 3 & 0,593 & 0,468 & Valid \\
\hline 4 & 0,692 & 0,468 & Valid \\
\hline 5 & 0,601 & 0,468 & Valid \\
\hline 6 & 0,716 & 0,468 & Valid \\
\hline 7 & 0,522 & 0,468 & Valid \\
\hline 8 & 0,564 & 0,468 & Valid \\
\hline 9 & 0,608 & 0,468 & Valid \\
\hline 10 & 0,497 & 0,468 & Valid \\
\hline 11 & 0,525 & 0,468 & Valid \\
\hline 12 & 0,720 & 0,468 & Valid \\
\hline
\end{tabular}

Pada tabel 4. diatas pada kolom Corrected Item-Total Correlation pada masing - masing atribut didapatkan nilai lebih dari $r$ tabel 0,468 . Jadi hasil kuisioner pada produk bahan bakar minyak tanah untuk masing - masing atribut dinyatakan valid.

Tabel 5. Output Uji Reliabilitas Hasil Kuisioner Bahan Bakar Briket

\begin{tabular}{|c|c|c|}
\hline $\mathrm{R}_{\text {tabel }}$ & Alpha & Keterangan \\
\hline 0,468 & 0,883 & Reliabel \\
\hline
\end{tabular}

Pada tabel 5. diatas nilai Cronbach's Alpha adalah sebesar 0,883, nilai yang didapat lebih dari 0,468, jadi hasil kuisioner untuk bahan bakar minyak tanah dinyatakan reliabel. $($ Reliabel $=$ Cronbach's Alpha $>0,468)$

Tabel 6. Output Uji Validitas Hasil Kuisioner Bahan Bakar Briket

\begin{tabular}{|c|c|c|c|}
\hline Atribute & R hitung & R tabel & Keterangan \\
\hline 1 & 0,798 & 0,468 & Valid \\
\hline 2 & 0,649 & 0,468 & Valid \\
\hline 3 & 0,556 & 0,468 & Valid \\
\hline 4 & 0,552 & 0,468 & Valid \\
\hline 5 & 0,588 & 0,468 & Valid \\
\hline
\end{tabular}




\begin{tabular}{|c|c|c|c|}
\hline 6 & 0,508 & 0,468 & Valid \\
\hline 7 & 0,665 & 0,468 & Valid \\
\hline 8 & 0,625 & 0,468 & Valid \\
\hline 9 & 0,546 & 0,468 & Valid \\
\hline 10 & 0,586 & 0,468 & Valid \\
\hline 11 & 0,506 & 0,468 & Valid \\
\hline 12 & 0,596 & 0,468 & Valid \\
\hline
\end{tabular}

Pada tabel 6. diatas pada kolom Corrected Item-Total Correlation pada masing - masing atribut didapatkan nilai lebih dari $\mathrm{r}$ tabel 0,468 . Jadi hasil kuisioner pada produk bahan bakar briket untuk masing - masing atribut dinyatakan valid.

\section{B. Perhitungan Game Theory}

Menurut J. Von Neumann, et al dalam Subagyo Pangestu Dkk, 2005, Game theory adalah suatu cara belajar yang digunakan dalam menganalisa interaksi antara sejumlah pemain maupun perorangan yang menunjukkan strategi-strategi yang rasional.

Tabel 7. Jumlah Hasil Kuisioner masing- masing Atribut Bahan Bakar

\begin{tabular}{|c|c|c|c|}
\hline \multirow{2}{*}{ Atribut } & \multicolumn{3}{|c|}{ Produk } \\
\cline { 2 - 4 } & LPG & Minyak tanah & Briket \\
\hline 1 & 36 & 81 & 81 \\
\hline 2 & 34 & 86 & 87 \\
\hline 3 & 82 & 60 & 54 \\
\hline 4 & 42 & 51 & 78 \\
\hline 5 & 82 & 61 & 61 \\
\hline 6 & 56 & 87 & 74 \\
\hline 7 & 91 & 31 & 29 \\
\hline 8 & 89 & 27 & 29 \\
\hline 9 & 73 & 44 & 71 \\
\hline 10 & 79 & 37 & 82 \\
\hline 11 & 61 & 52 & 80 \\
\hline 12 & 90 & 70 & 69 \\
\hline
\end{tabular}

Pada tabel 7 menjelaskan tentang jumlah masing masing atribut pada bahan bakar LPG, minyak tanah dan briket. Jumlah masing- masing atribut ini digunakan untuk perhitungan game theory.

Contoh perhitungan matriks pada Game theory, sebagai berikut :

Keterangan :

$\mathrm{P} 1=\mathrm{LPG}$

$\mathrm{P} 2=$ Minyak tanah

P3 =Briket

$$
\begin{aligned}
\% & =\frac{\mathrm{P} 1 \text { atribute } 1-\mathrm{P} 2 \text { atribute } 1}{20} \times 100 \% \\
& =\frac{36-81}{20} \times 100=-225
\end{aligned}
$$

$$
\begin{aligned}
\% & =\frac{\mathrm{P} 1 \text { atribute } 1-\mathrm{P} 3 \text { atribute } 3}{20} \times 100 \% \\
& =\frac{36-54}{20} \times 100=-90
\end{aligned}
$$

$\%=\mathrm{P} 2$ atribute $2-\mathrm{P} 1$ atribute $2-\times 100 \%$ 


$$
\begin{aligned}
& =\frac{86-34}{20} \times 100=260 \\
\% & =\frac{\mathrm{P} 2 \text { atribute } 2-\mathrm{P} 3 \text { atribute } 9}{20} \times 100 \% \\
& =\frac{86-71}{20} \times 100=75
\end{aligned}
$$

Tabel 8. Matrik Payoff antara LPG dengan Briket

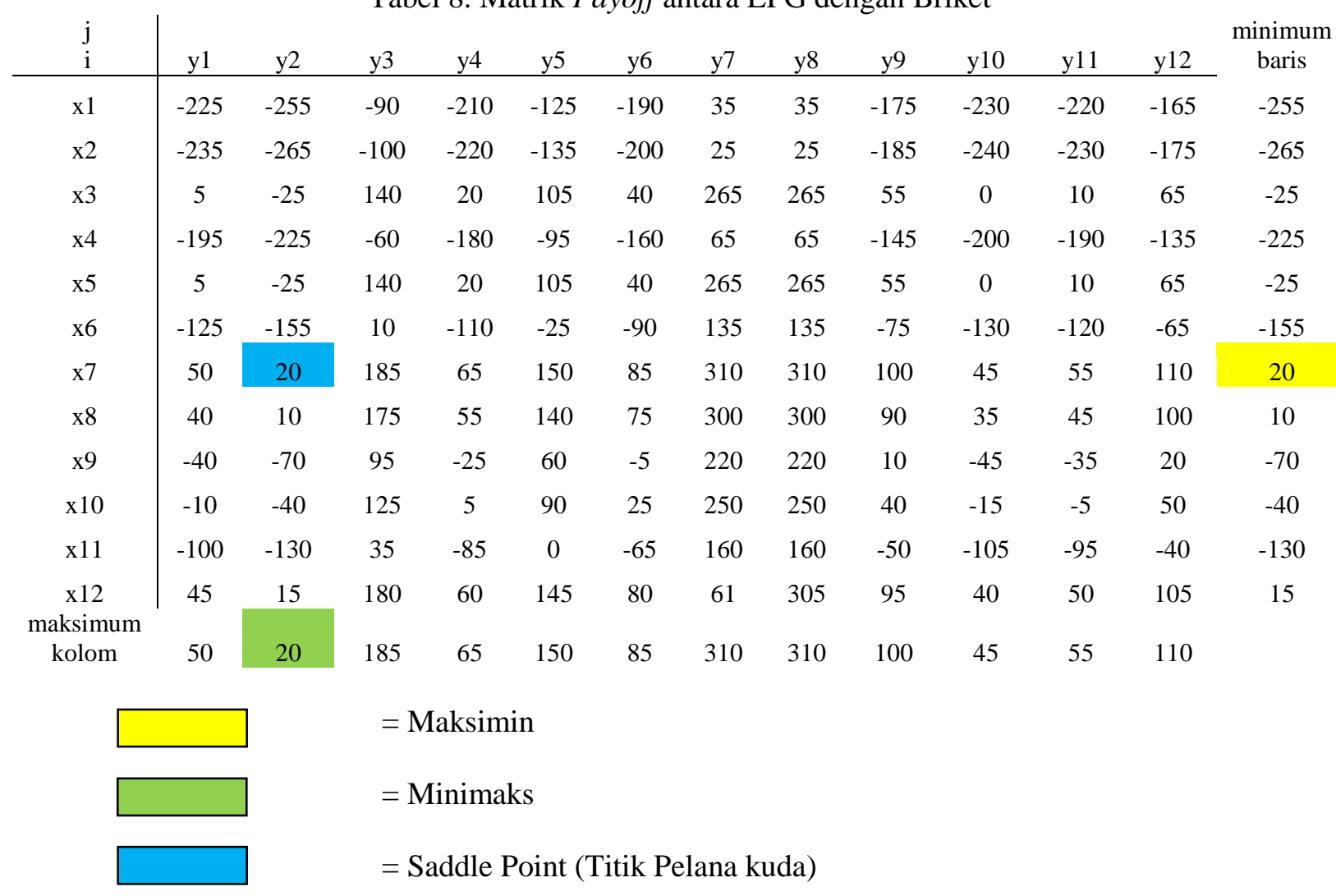

Tabel 8. menunjukkan Matrik Payoff antara LPG dengan Briket. Pada bagian ini hanya menampilkan satu contoh perhitungan matrik payoff.

\section{Strategi optimal tiap produk}

Hasil strategi optimal tiap produk didapat dari tabel matriks pada titik pelana kuda (saddle point) dalam nilai permainan dan ada pula strategi alternatif untuk memaksimalkan persaingan yang ada dijabarkan, sebagai berikut :

1. LPG

a. LPG dibandingkan dengan minyak tanah

Untuk melawan minyak tanah, LPG mengunakan strategi X7 (Mudah dijumpai di toko terdekat). Strategi ini dipilih karena pada tabel. 4.11 minimum baris menunjukan nilai minimaks 20. Adapun strategi alternatif yang bisa menjadi unggulan oleh produk LPG yaitu X12 (Mengetahui produk berdasarkan promosi) dengan nilai minimum 15 dan X8 (Stock produk selalu tersedia) dengan nilai minimum 10.

Namun produk LPG harus lebih meningkatkan dibeberapa strategi lain seperti pada kolom Y6 (Memiliki banyak kegunaan) dengan nilai maksimum 20, Y2 (Mudah dibawa) dengan nilai maksimum 25, dan Y1 (Mudah dikemas) dengan nilai maksimum 50 . 
b. LPG dibandingkan dengan briket

Untuk melawan briket, LPG mengunakan strategi X7 (Mudah dijumpai di toko terdekat). Strategi ini dipilih karena pada tabel. 4.12 minimum baris menunjukan nilai minimaks 20. Adapun strategi alternatif yang bisa menjadi unggulan oleh produk LPG yaitu X12 (Mengetahui produk berdasarkan promosi) dengan nilai minimum 15 dan X8 (Stock produk selalu tersedia) dengan nilai minimum 10.

Namun produk LPG harus lebih meningkatkan dibeberapa strategi lain seperti pada kolom Y2 (Mudah dibawa) dengan nilai maksimum 20, Y10 (Harga termasuk terjangkau) dengan nilai maksimum 45, dan Y1 (mudah dikemas) dengan nilai maksimum 50.

2. Minyak tanah

a. Minyak tanah dibandingkan dengan LPG

Untuk melawan LPG, minyak tanah mengunakan strategi X6 (Memiliki banyak kegunaan). Strategi ini dipilih karena pada tabel. 4.13 minimum baris menunjukan nilai minimaks -20. Adapun strategi alternatif yang bisa menjadi unggulan oleh produk minyak tanah yaitu X2 (Mudah dibawa) dengan nilai minimum -25 dan X1 (Mudah dikemas) dengan nilai minimum -50.

Namun produk minyak tanah harus lebih meningkatkan dibeberapa strategi lain seperti pada kolom Y7 (Mudah dijumpai di toko terdekat) dengan nilai maksimum -20, Y12 (Konsumen mengetahui produk berdasarkan promosi) dengan nilai maksimum -15 , dan Y8 (Stock selalu tersedia) dengan nilai maksimum -10 .

b. Minyak tanah dibandingkan dengan briket

Untuk melawan briket, minyak tanah mengunakan strategi X6 (Memiliki banyak kegunaan). Strategi ini dipilih karena pada tabel. 4.14 minimum baris menunjukan nilai minimaks 0. Adapun strategi alternatif yang bisa menjadi unggulan oleh produk minyak tanah yaitu X2 (Mudah dibawa) dengan nilai minimum -5 .

Namun produk minyak tanah harus lebih meningkatkan dibeberapa strategi lain seperti pada kolom Y10 (Harga termasuk terjangkau) dengan nilai maksimum 25 dan Y1 (Mudah dikemas) dengan nilai maksimum 30.

3. Briket

a. Briket dibandingkan dengan LPG

Untuk melawan LPG, briket mengunakan strategi X2 (Mudah dibawa). Strategi ini dipilih karena pada tabel. 4.15 minimum baris menunjukan nilai minimaks -20. Adapun strategi alternatif yang bisa menjadi unggulan oleh produk briket yaitu X10 (Harga termasuk terjangkau) dengan nilai minimum -45 dan X1 (Mudah dikemas) dengan nilai minimum -50.

Namun produk briket harus lebih meningkatkan dibeberapa strategi lain seperti pada kolom Y7 (Mudah dijumpai di toko terdekat) dengan nilai maksimum -20, Y12 (Konsumen mengetahui produk berdasarkan promosi) dengan nilai maksimum -15, dan Y8 (Stock selalu tersedia) dengan nilai maksimum -10 .

b. Briket dibandingkan dengan Minyak tanah

Untuk melawan minyak tanah, briket mengunakan strategi X2 (Memiliki banyak kegunaan). Strategi ini dipilih karena pada tabel. 4.16 minimum baris menunjukan nilai minimaks 0 . Adapun strategi alternatif yang bisa menjadi unggulan oleh produk minyak tanah yaitu X10 (harga termasuk terjangkau) dengan nilai minimum -25 .

Namun produk minyak tanah harus lebih meningkatkan dibeberapa strategi lain seperti pada kolom Y6 (Memiliki banyak kegunaan) dengan nilai maksimum 0 dan Y1 (Mudah dikemas) dengan nilai maksimum 30. 


\section{KESIMPULAN DAN SARAN}

\section{A. Kesimpulan}

Kesimpulan yang diperoleh dari analisa hasil dari teori permainan pada produk adalah : Briket mempunyai atribut yang lebih unggul ketika dibandingkan dengan LPG dan minyak tanah yaitu pada mudah dibawa, harga termasuk terjangkau bagi konsumen, dan mudah dikemas. Untuk lebih meningkat penjualan produk briket harus mengembangkan strategi yang dinilai masih lemah yaitu mudah dijumpai ditoko terdekat, konsumen mengetahui produk berdasarkan promosi, stock produk selalu tersedia, dan memiliki banyak kegunaan.

\section{B. Saran}

Saran berdasarkan penelitian tentang pemasaran dan teori permainan yang sudah dilakukan adalah :

1. Penelitian ini bisa dikembangkan dengan menggunakan metode lain dan berdasarkan perubahan pasar pertahunnya, sehingga penelitian ini bisa dibandingkan untuk memperoleh hasil yang lebih baik.

2. Untuk penelitian selanjutnya sebaiknya mengunakan jumlah kuisioner lebih banyak agar kemungkinan realibitis dan validitas lebih besar karena peran kuisioner dapat mempengaruhi hasil dan kualitas dari penelitian.

3. Penelitian ini mengunakan 3 produk untuk dibandingkan kemungkinan ada produk bahan bakan yang bisa dibandingkan dalam persaingan pasar produk bahan bakar.

\section{DAFTAR PUSTAKA}

[1] Agusyana Yus, 2011, "SPSS 19.0”, Jakarta :Exel media Komputerindo.

[2] Assuri Sofjan, 2011, "Manajemen pemasaran", Jakarta :Edisi 11 KHARISMA.

[3] Donoriyanto D. S, 2013. "Penentuan Strategi Pemasaran pada Produk Minuman Berenergi", Jurnal Ilmiah Mahasiswa Universitas Surabaya Vol.2, No.1 Hal 11 - 18.

[4] Gunawan Wahyu T, 2013. " Pembauran Pemasaran dan Kualitas Layanan Pengaruhnya terhadap Kepuasan Pelanggan”, Jurnal EMBA, Vol 1, No. 4, Hal 2049 - 2058.

[5] Karolina, Surjani. Rosita. M, Rinawiyanti Esti. D, 2013. Perancangan Strategi Pemasaran Berbasis Prilaku Konsumen, Jurnal Penelitian Ilmu Teknik,Vol.10, No.1, hal 11-18.

[6] McCarthy E. Jerome, Perreault William D, 1993. "Dasar-Dasar Pemasaran”, Jakarta : Edisi 5 ERLANGGA

[7] Rachmawati R., "Peran pembauran pemasaran (marketing mix) terhadap peningkatan penjualan", Jurnal Kompetensi Teknik, Vol. 2, No. 2, Hal 143 - 149.

[8] Shabastian M, Samuel Hatate, 2013. "Pengaruh strategi harga dan dan strategi produk terhadap brand loyalty”, Jurnal Manajemen pemasaran, Vol. 1, No.1, Hal 1 9.

[9] Simamora C. H, Rosmaini Elly, Napitupulu Normalina, 2013. "Penerapan teori permainan dalam strategi pemasaran", Jurnal Saintia Matematika, Vol. 1, No. 2, Hal $129-137$.

[10] Siswanto, 2007, “Operations Research jilid II”, Jakarta : ERLANGGA.

[11] Siviana, 2012. "Penerapan strategi pemasaran marketing mix", Jurnal Widya Teknika, Vol. 20, No. 1, Hal 55 - 62.

[12] Subagyo P, Asri Marwan, Handoko T. Hani, 2005, "Dasar-dasar operation research", Yogyakarta :Edisi 2 BPFE.

[13] Wahyudi Tri, Prawatya Yopa. E, 2012, “Analisa pengaruh marketing mix terhadap kepuasaan konsumen", Jurnal Elkha, Vol. 4, No. 2, Hal 34 - 37. 
